\title{
Diabetes Mellitus: Disorder of Cellular Dysfunction Due to Lack of Entry into Cell of Glucose. The Most Efficient Fuel for Cellular Function*
}

\author{
Udaya M. Kabadi 1 ,2,3 \\ ${ }^{1}$ Broadlawns Medical Center, Des Moines, USA \\ ${ }^{2}$ University of Iowa, Iowa, USA \\ ${ }^{3}$ Des Moines University, Des Moines, USA \\ Email: ukabadi@gmail.com
}

How to cite this paper: Kabadi, U.M. (2021) Diabetes Mellitus: Disorder of Cellular Dysfunction Due to Lack of Entry into Cell of Glucose. The Most Efficient Fuel for Cellular Function. Open Journal of Endocrine and Metabolic Diseases, 11, 79-101. https://doi.org/10.4236/ojemd.2021.113007

Received: February 25, 2021

Accepted: March 28, 2021

Published: March 31, 2021

Copyright $\odot 2021$ by author(s) and Scientific Research Publishing Inc. This work is licensed under the Creative Commons Attribution International License (CC BY 4.0).

http://creativecommons.org/licenses/by/4.0/

\begin{abstract}
Background: Diabetes Mellitus is established to be a chronic hyperglycemic disorder secondary to altered glucose metabolism. Alternatively, hyperglycemia may be one of several manifestations in subjects with type 1 and type 2 diabetes Mellitus. Most tissues require insulin for entry of glucose, exceptions being red blood cells, renal medulla and nervous system. Hyperglycemia in intravascular compartment and other extra cellular milieu may be attributed to impaired glucose entry into endothelial cells of the vessel wall and cells in other tissues due to absence of insulin in type 1 and both insulin resistance and decline in insulin secretion in type 2 Diabetes. Objective: Hypothesis is proposed that Diabetes mellitus is a disorder of cellular dysfunction due to lack of entry of glucose, the most efficient fuel. Literature review was conducted to establish the perspective. Results: Declines in both phases of insulin secretion are induced by lack of glucose entry into pancreatic beta cells. Hyperglycemia is perpetuated by increased hepatic glucose production caused by sustained hyperglucagonemia secondary to lack of glucose entry into the pancreatic alpha cells. Moreover, decline in insulin secretion by beta cells and rise in glucagon release by alpha cells are enhanced by fall in GLP1 and GIP caused by dysfunction of $\mathrm{L}$ cells and $\mathrm{K}$ cells secondary to lack of glucose entry in both types of diabetes. Increased prevalence of infections and thromboembolic events may be attributed to dysfunction of leukocytes and platelets due to impaired glucose entry. Finally, alterations in metabolemics including Adiponectin, TNF alpha, Plasminogen inhibitor factor 1, Homocysteine, CRP, Lipids etc. as
\end{abstract}

${ }^{\star}$ The data was presented in part at International Congress of Endocrinology in December 2018 in Cape Town, South Africa. 
well as dysfunction of several organs in both types of diabetes may also be attributed to the lack of glucose entry into specific cells. Hypothesis is validated by improvement in metabolemics and organ function on facilitation of glucose entry into cells by insulin administration and/or improvement in insulin sensitivity. Conclusion: Diabetes mellitus is a disorder manifesting dysfunction involving almost all organs and cells induced by lack of entry of glucose, the most efficient substrate for cellular function.

\section{Keywords}

Diabetes Mellitus, Cellular Dysfunction, Cellular Glucose Entry

\section{Introduction}

Traditionally, diabetes Mellitus has been deemed to be a chronic hyperglycemic disorder secondary to altered glucose metabolism [1]. Alternatively, hyperglycemia may be one of several manifestations in subjects with type 1 and type 2 diabetes Mellitus [1]-[6]. Almost all tissues require insulin for entry of glucose, the possible exceptions being red blood cells, renal medulla, lens as well as central and peripheral nervous systems. However, some recent studies have documented the role of insulin in glucose uptake by the brain and other nervous tissues [1]-[6]. Thus, hyperglycemia in extra cellular milleau including intravascular compartment may be attributed to impaired glucose entry into all cells including hepatocytes, myocytes and adipocytes and even endothelial cells of the vessel wall due to absence of insulin in type 1 and both the insulin resistance and the decline in insulin secretion in type 2 Diabetes [6] [7] [8][9] [10].

\section{Pancreatic Dysfunction}

In subjects with both type 1 and type 2 diabetes as well as Prediabetes, post prandial hyperglycemia is the initial manifestation induced by the decline in the 1st phase insulin secretion due to inhibited release of stored insulin [7] [11] [12] [13] [14]. Overall diurnal hyperglycemia is further exacerbated later by a marked rise in the inter meal and fasting hyperglycemia caused by the lowering of 2 nd phase insulin release [11] [12] [13] [14]. Albeit, the declines in both phases of insulin secretion in type 2 diabetes are induced by lack of glucose entry into pancreatic beta cells as a result of insulin resistance at the beta cells themselves [11] [12] [13]. Finally, progressive beta cell failure described as a natural course of type 2 diabetes is apparently neither universal nor total and therefore may be limited to subjects not attaining and maintaining desirable glycemic control [14]-[24]. Moreover, recent studies have documented that beta cell failure is reversible and preventable by sustained glycemic control [21] [22] [23] [24]. Finally another study recently demonstrated differentiation of beta cells into empty cells devoid of insulin secretory granules in subjects with type 2 diabetes with persistent lapse of glycemic control [16]. Therefore, these findings may be con- 
sistent with the reported gradually declining beta cell function which may be attributed to persistent lack of glucose entry into beta cells. Similar progression in type 1 diabetes may be attributed to the same pathophysiology induced by declining circulating insulin due to autoimmune destruction of beta cells.

Sustained circulating hyperglucagonemia ensues due to the lack of glucose entry into pancreatic alpha cells rendering them incapable of recognition of circulating hyperglycemia [25]-[31]. Elevated circulating glucagon in turn promotes hepatic glucose production via glycogenolysis and gluconeogenesis with consequential exacerbation of diurnal hyperglycemia.

Alternatively, the decline in insulin secretion by the beta cells and the rise in glucagon release by the alpha cells is also induced by the fall in in Incretins namely GLP1 and GIP caused by dysfunction of L cells in the duodenum and $\mathrm{K}$ cells in ileum respectively [32] [33] [34] [35] [36]. The decline in incretin effect may be secondary to lack of glucose entry into these cells due to absence of insulin in type 1 and both the insulin resistance as well as decreased insulin secretion in type 2 diabetes. Alternatively, increased DPP4 activity documented in both type 1 and type 2 diabetes may be responsible for enhanced degradation of Incretins and exacerbate the decline in their circulating levels [37] [38]. The hypothesis is also consistent with available data in literature documenting lowering of plasma glucagon and rise in insulin directly as well as via increase in GLP1 and GIP concentrations on improvement in insulin sensitivity following treatment with insulin sensitizers e.g. metformin or glitazones in type 2 diabetes and by insulin administration in both type 1 and type 2 diabetes [39]-[47]. Finally, alteration of other pancreatic hormones, e. g. amylin, pancreastatin, somatostatin as well as pancreatic polypeptide are documented in both type 1 and type 2 diabetes and may be secondary to dysfunction of other pancreatic endocrine cells due to lack of glucose entry by the same aforementioned mechanism [48] [49] [50]. Finally, hyperglucagonemia occurs despite euglycemia in several disorders and states associated with insulin resistance and may be attributed to inhibited glucose entry into alpha cells [25].

The hypothesis may be extended to dysfunction of the exocrine pancreas since serum pancreatic amylase and lipase concentrations are frequently elevated in subjects with acute lapse of glycemic control, especially diabetic Ketoacidosis and hyperglycemic hyperosmolar nonketotic state [51] [52]. Similarly, more frequent occurrence of pancreatitis, often without a ductal calculus may be secondary to lack of glucose entry into ductal cells as well as the cells of the ampulla of Vatter respectively. Finally, greater prevalence of pancreatic maldigestion in subjects with diabetes of both types may attributed to the same pathophysiology [53] [54] [55] [56].

\section{Hepatic Dysfunction}

Elevations in serum concentrations of liver enzymes especially transaminases are a frequent finding in subjects with diabetes as well as prediabetes attributed to nonalcoholic steatohepatitis [NASH] or "fatty liver" [57] [58] [59]. The patho- 
physiology of "fatty liver" in these disorders is well defined. Hepatic conversion of very low density lipoprotein [VLDL] into low density lipoprotein [LDL] is promoted by insulin sensitive hepatic lipoprotein lipase or triglyceride hydrolase. Therefore, this pathway is inhibited in both type 1 and type 2 diabetes due lack of adequate circulating insulin or presence of insulin resistance leading to rise in serum triglycerides, the major constituent of VLDL cholesterol fraction. Alternatively, lack of circulating insulin or insulin resistance promotes tissue lipolysis with excessive accumulation of free fatty acids in the circulation, the substrate for hepatic triglyceride synthesis. A portion of the increased hepatic triglycerides leaks into circulation and contributes to further elevation of serum concentration while the remnant is stored in the hepatic parenchyma leading to fatty liver or NASH [57] [58] [59]. This pathophysiology of NASH is confirmed by resolution of NASH following insulin administration in subjects with both type 1 and type 2 diabetes as well as insulin secretogogues and insulin sensitizers in population with both prediabetes and type 2 diabetes [57]-[69].

The rise in cytokines; interleukins and $\mathrm{C}$ reactive protein in presence of inflammation and infection, the rise in fibrinogen, plasminogen activation inhibitor [PAI] 1 promoting platelet aggregation and coagulation as well as the increase in other Metabolemics including uric acid, homocysteine Hepatocyte nuclear factor, resistin, growth factors etc. may be secondary to hepatocellular dysfunction induced by the lack of glucose entry into hepatocytes [70]-[75]. Improvement in serum concentrations of these metabolites following administration of insulin sensitizers and/or insulin secretogogues and/or insulin itself in subjects with type 2 diabetes and Prediabetes further enhance this hypothesis [76] [77] [78] [79]. Finally, alterations in several other metabolmics in both type 1 and type 2 diabetes may also be attributed to the lack of glucose entry into specific cells generating these metabolemics and this pathophysiology is confirmed by reversal towards normalization following promoting glucose entry into these cells by appropriate therapies [70]-[79].

\section{Dysfunction of Adipocytes}

Until recently, adipose tissue was labeled as a storage organ. However, several recent studies have established adipose tissue to an endocrine organ since it synthesizes and releases several humoral factors recognized as adipokines [80]-[95]. These include leptin, adiponectin, complement components, plasminogen activator inhibitor-1, proteins of the renin-angiotensin system, and resistin as well as other cytokines, e.g. fibroblast growth factor 21 [FGF21], retinol-binding protein 4 [RBP4], dipeptidyl peptidase 4 [DPP-4], bone morphogenetic proteins, [BMP-4 and BMP-7], vaspin, apelin, and progranulin, spexin etc. Secretion of adipokines is altered due to adipose tissue dysfunction and may contribute to a spectrum of obesity-associated diseases including Prediabetes and type 2 diabetes [81] [82] [86]-[91]. We postulate that adipose tissue dysfunction in both Prediabetes and type 2 diabetes is caused by lack of entry of glucose into adipo- 
cytes secondary to insulin resistance since similar alterations in adipokines are documented in type 1 diabetes probably by the same mechanism due to lack of circulating insulin [84] [85]. However, the changes in adipokines were dissimilar in comparison to type 2 diabetes as noted by a rise in circulating adiponectin and leptin concentrations at onset of type 1 diabetes followed by a fall with increasing duration of the disorder. Increase at the onset may be attributed to enhanced entry of glucose into adipocytes secondary to insulin hypersensitivity in presence of residual beta cell function. Ensuring fall in adipokines with increasing duration of the disorder appears to be induced by lack of entry of glucose into adipocytes due declining insulin sensitivity and absence of circulating insulin due to progressive destruction of beat cells [84] [85]. The hypothesis is further established by rise in adipokines by blunting of insulin resistance in insulin resistant states and administration of insulin in type 1 diabetes [92] [93] [94] [95].

\section{Blood Corpuscular Dysfunction}

Increase in both the infection rates and thromboembolic events in hospitalized subjects with hyperglycemia even in the absence of the diagnosis of Diabetes and the improvement in outcomes following a prompt treatment with insulin infusion have been well documented [96]-[104]. Similarly, ambulatory subjects with both type 1 and type 2 diabetes with persistent hyperglycemia are predisposed to recurrent infections, macro vascular outcomes including thromboembolic events as well as microvascular complications [96]-[103] [105] [106]. Increased infections may be attributed to decreased phagocytosis due to dysfunction of white blood cells secondary to lack of entry of glucose induced by insulin resistance and a relative decline or total lack in circulating insulin in both the hospitalized subjects with hyperglycemia as well as ambulatory population with type 2 and type 1 diabetes respectively. The dysfunction of platelets due to lack of glucose entry may be responsible for their enhanced aggregability promoting increase prevalence of thromboembolic events. Adverse macro vascular outcomes are further facilitated by increase viscosity induced by hyperglycemia and its consequential dehydration as well as increased circulating triglycerides [107] [108] [109].

\section{Muscular Dysfunction}

Lack of glucose entry results in voluntary muscle wasting, weakness and serum irisin with hyperglycemia in subjects with diabetes of both types followed by a recovery and reversal to normal function on attaining and maintaining Glycemic control [110]-[115]. Similarly, involvement of muscles of viscera and their respective sphincters lead to several systemic disorders including [1] GI Tract: Dysphagia, Gastroparesis, Enteropathy, [2] Genitourinary Tract: Retrograde Ejaculation and Erectile Dysfunction in men as well as Dyspareunia and Lack of Orgasm in women [116] [117] [118] [119]. Finally, persistent hyperglycemia due 
to lack of glucose entry leads to dysfunction of cardiomyocytes resulting in both Acute Coronary Syndrome as well as cardiomyopathy [119]. Higher the plasma glucose, larger is the size of infarction with increasing mortality as well as morbidity e.g congestive heart failure, cardiogenic shock resulting in longer hospital stay and greater costs [104]. Recent studies have demonstrated improvement in all endpoints by continuous Insulin infusion promoting enhanced Glucose entry into myocardial cells [104].

\section{Pulmonary Dysfunction}

Decline In Lung Volumes, FEV1, FVC and Diffusion capacity ensue with aging as well as in obese subjects with further exaggeration in presence of diabetes leading to worsening restrictive pulmonary disease frequently resulting in onset of Cor pulmonale [120] [121] [122] [123] These manifestations may be attributed to unifying mechanism; lack of entry of Glucose into alveolar cells and respiratory Muscles of Chest, Diaphragm secondary to insulin resistance as well as a relative or absolute decline in insulin secretion [104].

\section{Bone Disorder}

Osteocytes require glucose as a fuel for optimal function. Bone mineral density declines with aging, obesity as well as persistent hyperglycemia in subjects with diabetes [124]-[129]. Multiple pathophysiologic mechanisms appear to play a role. Insulin resistance as well as deficiency activate osteoclasts promoting bone resorption. Concurrently, inhibition of osteoblasts ensues decreasing compensatory bone formation resulting in osteoporosis. Moreover, rising concentrations of counter regulatory hormones, e.g., glucagon, cortisol etc. induce decline in matrix via promoting gluconeogenesis from collagen also resulting in osteoporosis. Alternatively, hypercortisolemia also directly facilitates osteoporosis as well as osteomalacia due to decline in circulating active $125 \mathrm{OH}$ vitamin D via inhibition of hepatic 25 hydroxylase. Finally, increased urinary excretion of calcium and phosphate leads to rise in PTH exacerbating bone resorption. Therefore, osteoporosis is a frequent sequel of both type 1 and 2 diabetes secondary to impaired entry of glucose into osteocytes due to lack of insulin and insulin resistance respectively. Improvement in bone mineral density ensues following attaining and maintaining Glycemic control [128] [129] [130] [131] [132].

\section{Hypothalamic Pituitary Dysfunction}

Inappropriately high serum concentrations of human growth hormone and $\mathrm{ACTH}$ are well documented to occur in presence of uncontrolled hyperglycemia e.g. Diabetic ketoacidosis and hyperosmolar state in both type 1 and type 2 diabetes [133]-[139]. The disruption of feedback regulation between glucose and HGH as well as ACTH secretion is accompanied by inhibitions of both hypothalamic Pituitary gonadal and thyroid axes [140]-[152]. Finally, Pituitary dependent endocrine glands fail to function appropriately as well resulting in altered circulating 
concentrations of hormones synthesized and secreted by these glands with consequential rise in cortisol and declines in thyroid and gonadal hormones [137][153]. These aberrations may be attributed to lack of glucose entry into hypothalamus and various Pituitary cells as well as Pituitary dependent endocrine cells induced by insulin deficiency in type 1 and insulin resistance in type 2 diabetes. Furthermore, thyroid hormonal changes in various "Euthyroid Sick States" and gonadal dysfunction in PCOS and obese subjects are also attributed to insulin resistance at the level of thyroid gland as well as hormonal metabolism in peripheral tissues as well as on the part of ovarian theca cells respectively [147] [154]-[163]. Alternatively, metabolemic changes in several chronic disorders including HIV syndrome, chronic renal failure, malignancy etc. as well as in subjects hospitalized for treatment of acute illnesses may be attributed the same pathphysiologic mechanism [147] [164] [165] [166]. I believe that this pathophysiologic hypothesis is confirmed by normalization of function of these hypothalamic Pituitary axes and Pituitary dependent endocrine cells in response to timely improvement in Glycemic milieu following prompt therapy with insulin [104] [162] [163] [167] [168] [169] [170] [171].

Finally, improved outcomes e.g. prompt remission, delay or prevention of recurrences as well as longer survival are reported recently by adjunctive therapy with Metformin or thiazolidinediones in combination with chemotherapy in subjects with various cancers [168] [169] [170]. These benefits may be attributed to enhanced entry of chemotherapeutic agents along with glucose into cancer cells secondary to blunting of insulin resistance present in subjects manifesting cancer. However, a distinct concern exists regarding increased adverse effects induced by entry of chemotherapeutic agent into normal cells.

\section{Intravascular Hyperglycemia and Its Consequences}

Lack of entry into endothelial cells lining the vessel wall leads both endothelial dysfunction and intravascular hyperglycemia [172]-[178]. Endothelial dysfunction plays a prominent role in exacerbating atherosclerosis in vessels of all sizes resulting in adverse outcomes of both macro vascular and micro vascular variety [169]-[175]. Macro vascular outcomes are further facilitated by increased viscosity induced by dehydration secondary to enhanced diuresis caused by intravascular hyperglycemia. Moreover, intravascular hyperglycemia is responsible for clinical manifestations of diabetes e.g. Polyuria, nocturia, polydypsia, polyphagia etc as well as other acute metabolic aberrations including DKA, Hyperglycemic hyperosmolar state, hypertriglyceridemia etc. Moreover, circulating glucose is metabolized by an alternative polyol pathway with generation of sorbitol by conversion of fructose by aldose reductase [179] [180] [181] [182]. Sorbitol in turn is deposited in various tissues causing other manifestations i.e. blurred vision, acutely and cataracts chronically secondary to deposition in lens; change in mental status secondary to cerebral edema induced by osmotic disequilibrium due to exaggerated entry of glucose into brain; peripheral neuropathy with pa- 
rasthesia and hypoasthesia as well autonomic neuropathy with acute orthostasis, gastrectasia, erectile dysfunction etc. caused by deposition in neurilemmal sheaths as well as proteinuria resulting from deposition in renal tubules [179] [180] [181] [182]. Fortunately, all these manifestations are transient and are remitted because this metabolic polyol pathway is reversible following improvement in glycemic control. Moreover, aldose reductase inhibitors prevent or induce a prompt reversal of these complications [182] [183] [184].

Finally, persistent hyperglycemia enhances glycation of multiple proteins also termed as "advanced glycated products" [185]-[190]. Deposition of these products into various organs leads to chronic deadly and often disabling micro vascular complications including nephropathy, neuropathy and retinopathy [17] [18] [19] [20] [185]-[190]. Thus, it is apparent that lack of entry into endothelial cells lining the vessel wall contributes to their dysfunction and results in several adverse outcomes [172]-[178]. Moreover, consequential increased intravascular Glycemic load facilitates other acute manifestations and chronic complications. The hypothesis is further established by improvement in all outcomes by enhancement of entry of glucose into endothelial cells by insulin therapy in both type 1 and type 2 diabetes as well as insulin secretogogs and sensitizers in type 2 diabetes [17] [18] [19] [20] [104] [191]-[203].

In the final analysis, many clinical manifestations, metabolic aberrations and various chronic complications in both type 1 and type 2 diabetes as well as other insulin resistant states may be attributed to dysfunction of cells secondary to inhibited entry of glucose; specific cells requiring insulin for glucose entry. Alternatively, dysfunction of cells not requiring insulin for glucose entry ensues due to excessive accumulation of glucose and contributes to other remaining sequels and metabolic abnormalities. Remission from clinical manifestations and prevention and/ or delay in onset of chronic complications by appropriate therapies in both type 1 and type 2 diabetes and other insulin resistant states enhances the hypothesis.

\section{Acknowledgements}

Author expresses appreciation to Sarah Exley for assistance in preparation of manuscript.

\section{Conflicts of Interest}

The author declares no conflicts of interest regarding the publication of this paper.

\section{References}

[1] Brunton, S. (2016) Pathophysiology of Type 2 Diabetes: The Evolution of Our Understanding. The Journal of Family Practice, 65.

[2] DeFronzo, R.A., Eldor, R. and Abdul-Ghani, M. (2013) Pathophysiologic Approach to Therapy in Patients with Newly Diagnosed Type 2 Diabetes. Diabetes Care, 36, S127-S138. https://doi.org/10.2337/dcS13-2011 
[3] Hugenschmidt, C.E. (2013) A Link between Type 2 Diabetes and Brain Function. Journal of the American Academy of Physician Assistants, 26, 10-11. https://doi.org/10.1097/01.JAA.0000437750.76865.61

[4] Zaccardi, F., Webb, D.R., Yates, T. and Davies, M.J. (2016) Pathophysiology of Type 1 and Type 2 Diabetes Mellitus: A 90-Year Perspective. Postgraduate Medical Journal, 92, 63-69. https://doi.org/10.1136/postgradmedj-2015-133281

[5] Javeed, N. and Matveyenko, A.V. (2018) Circadian Etiology of Type 2 Diabetes Mellitus. Physiology, 33, 138-150. https://doi.org/10.1152/physiol.00003.2018

[6] Henning, R.J. (2018) Type-2 Diabetes Mellitus and Cardiovascular Disease. Future Cardiology, 14, 491-509. https://doi.org/10.2217/fca-2018-0045

[7] Kabadi, U.M. (2017) Major Pathophysiology in Prediabetes and Type 2 Diabetes: Decreased Insulin in Lean and Insulin Resistance in Obese. Journal of the Endocrine Society, 1, 742-750. https://doi.org/10.1210/js.2016-1116

[8] Barnett, R. (2018) Type 1 Diabetes. The Lancet, 391, 195. https://doi.org/10.1016/S0140-6736(18)30024-2

[9] (2018) What You Should Know About Type 1 Diabetes. American Family Physician, 1, 1997-1998.

[10] Dayan, C.M., Korah, M., Tatovic, D., Bundy, B.N. and Herold, K.C. (2019) Changing the Landscape for Type 1 Diabetes: The First Step to Prevention. The Lancet, 394, 1286-1296. https://doi.org/10.1016/S0140-6736(19)32127-0

[11] Korytkowski, M., Thomas, A., Reid, L., et al. (2002) Glimepiride Improves Both First and Second Phases of Insulin Secretion in Type 2 Diabetes. Diabetes Care, 25, 1607-1611. https://doi.org/10.2337/diacare.25.9.1607

[12] Kabadi, M.U. and Kabadi, U.M. (2004) Effects of Glimepiride on Insulin Secretion and Sensitivity in Patients with Recently Diagnosed type 2 Diabetes Mellitus. Clinical Therapeutics, 26, 63-69. https://doi.org/10.1016/S0149-2918(04)90006-9

[13] Kabadi, U.M. and Kabadi, M. (2011) Early Postprandial Insulin Secretion: Its Relation to Insulin Sensitivity. Journal of Diabetes Mellitus, 1, 1-5.

https://doi.org/10.4236/jdm.2011.11001

[14] Kabadi, U., Kabadi, M.U., Weber, S., Bubolz, A. and Finnerty, E. (2015) Progressive $\beta$-Cell Failure in Type 2 Diabetes Mellitus: Microvascular Pancreatic Isletopathy? Journal of Diabetes Mellitus, 5, 21-27. https://doi.org/10.4236/jdm.2015.51003

[15] Kabadi, U. (2017) Major Pathophysiology in Prediabetes and Type 2 Diabetes: Decreased Insulin in Lean and Insulin Resistance in Obese. Journal of the Endocrine Society, 1, 742-750. https://doi.org/10.1210/js.2016-1116

[16] Cinti, F., Bouchi, R., Kim-Muller, J.Y., et al. (2016) Dysfunction of Pancreatic Beta Cells: Dedifferentiation into Other Empty Cells. The Journal of Clinical Endocrinology \& Metabolism, 101, 1048-1054.

[17] UK Prospective Diabetes Study Group (1998) Intensive Blood-Glucose Control with Sulphonylureas or Insulin Compared with Conventional Treatment and Risk of Complications in Patients with Type 2 Diabetes (UKPDS 33). The Lancet, 352, 837853. https://doi.org/10.1016/S0140-6736(98)07019-6

[18] UK Prospective Diabetes Study Group (1998) Effect of Intensive Blood-Glucose Control with Metformin on Complications in Overweight Patients with Type 2 Diabetes (UKPDS 34). The Lancet, 352, 854-865.

https://doi.org/10.1016/S0140-6736(98)07037-8

[19] UK Prospective Diabetes Study Group (1995) U.K. Prospective Diabetes Study 16: Overview of 6 Years' Therapy of Type II Diabetes: A Progressive Disease. Diabetes, 
44, 1249-1258. https://doi.org/10.2337/diab.44.11.1249

[20] Kabadi, U.M. (2002) United Kingdom Prospective Diabetes Study: A Different Perspective. Endocrine Practice, 8, 61. https://doi.org/10.4158/EP.8.1.61

[21] Jain, R., Kabadi, U. and Kabadi, M. (2008) Is Beta Cell Failure in Type 2 DM Reversible? International Journal of Diabetes in Developing Countries, 28, 1-5.

[22] Kabadi, U.M. and Exley, S. (2018) Progressive Beta Cell Failure in Type 2 Diabetes: Influence of Aging and Not Duration of Diabetes. International Congress of Endocrinology, Abstract ID: 366.

[23] Banzal, S. and Kabadi, U.M. (2019) Better Glycemic Control with Less Insulin on Transition from Continuous Subcutaneous Insulin Infusion to Basal Insulin Combined GLP1 Receptor Agonist and/or Metformin and Sulfonylurea. Journal of Diabetes, Obesity and Metabolism, 2, 1-8.

[24] Kabadi, U.M. (2013) Comparative Efficacy between Glimepiride and Metformin in Preventing Progression of Prediabetes to Type 2 Diabetes. Journal of Diabetes Mellitus, 3, 129-133. https://doi.org/10.4236/jdm.2013.33019

[25] Kabadi, U.M. (1993) Hepatic Regulation of Pancreatic Alpha-Cell Function. Metabolism, 42, 535-543. https://doi.org/10.1016/0026-0495(93)90208-6

[26] Lee, Y.H., Wang, M.Y., Yu, X.X. and Unger, R.H. (2016) Glucagon Is the Key Factor in the Development of Diabetes. Diabetologia, 59, 1372-1375.

https://doi.org/10.1007/s00125-016-3965-9

[27] Holst, J.J., Holland, W., Gromada, J., Lee, Y., Unger, R.H., Yan, H., Sloop, K.W., Kieffer, T.J., Damond, N. and Herrera, P.L. (2017) Insulin and Glucagon: Partners for Life. Endocrinology, 158, 696-701. https://doi.org/10.1210/en.2016-1748

[28] Stern, J.H., Smith, G.I., Chen, S., Unger, R.H., Klein, S. and Scherer, P.E. (2019) Obesity Dysregulates Fasting-Induced Changes in Glucagon Secretion. Journal of Endocrinology, 243, 149-160. https://doi.org/10.1530/JOE-19-0201

[29] Ichikawa, R., Takano, K., Fujimoto, K., Motomiya, T., Kobayashi, M., Kitamura, T. and Shichiri, M. (2019) Basal Glucagon Hypersecretion and Response to Oral Glucose Load in Prediabetes and Mild Type 2 Diabetes. Endocrine Journal, 29, 663-675.

[30] Nicolai, J., Albrechtsen, W., Pedersen, J., Galsgaard, K.D., Winther-Sørensen, M., Suppli, M.P., Janah, L., Gromada, J., Vilstrup, H., Knop, F.K. and Holst, J.J. (2019) The Liver-a-Cell Axis and Type 2 Diabetes. Endocrine Reviews, 40, 1353-1366. https://doi.org/10.1210/er.2018-00251

[31] Komada, H., Hirota, Y. and Ogawa, W. (2019) Glucagon Secretions Are Impaired in Patients with Fulminant Type 1 Diabetes. Journal of Diabetes Investigation, 10, 866-867. https://doi.org/10.1111/jdi.13041

[32] Nauck, M.A. and Meier, J.J. (2016) The Incretin Effect in Healthy Individuals and those with Type 2 Diabetes: Physiology, Pathophysiology, and Response to Therapeutic Interventions. Lancet Diabetes \& Endocrinology, 4, 525-536. https://doi.org/10.1016/S2213-8587(15)00482-9

[33] Holst, J.J., Albrechtsen, N.J.W., Rosenkilde, M.M. and Deacon, C.F. (2019) Physiology of the Incretin Hormones, GIP and GLP-1-Regulation of Release and Posttranslational Modifications. Comprehensive Physiology, 9, 1339-1381. https://doi.org/10.1002/cphy.c180013

[34] Holst, J.J. (2019) The Incretin System in Healthy Humans: The Role of GIP and GLP-1. Metabolism, 96, 46-55. https://doi.org/10.1016/j.metabol.2019.04.014

[35] Shah, F.A., Mahmud, H., Gallego-Martin, T., Jurczak, M.J., O’Donnell, C.P. and McVerry, B.J. (2019) Therapeutic Effects of Endogenous Incretin Hormones and 
Exogenous Incretin-Based Medications in Sepsis. Journal of Clinical Endocrinology \& Metabolism, 104, 5274-5284. https://doi.org/10.1210/jc.2019-00296

[36] Chia, C.W. and Egan, J.M. (2020) Incretins in Obesity and Diabetes. Annals of the New York Academy of Sciences, 1461, 104-126. https://doi.org/10.1111/nyas.14211

[37] Barchetta, I., Ciccarelli, G., Barone, E., Cimini, F.A., Ceccarelli, V., Bertoccini, L., Sentinelli, F., Tramutola, A., Del, B.M., Angelico, F., Baroni, M.G., Lenzi, A. and Cavallo, M.G. (2019) Greater Circulating DPP4 Activity Is Associated with Impaired Flow-Mediated Dilatation in Adults with Type 2 Diabetes Mellitus. Nutrition, Metabolism and Cardiovascular Diseases, 29, 1087-1094. https://doi.org/10.1016/j.numecd.2019.07.010

[38] Sarkar, J., Nargis, T., Tantia, O., Ghosh, S. and Chakrabarti, P. (2019) Increased Plasma Dipeptidyl Peptidase-4 (DPP4) Activity Is an Obesity-Independent Parameter for Glycemic Deregulation in Type 2 Diabetes Patients. Frontiers in Endocrinology, 10, 505. https://doi.org/10.3389/fendo.2019.00505

[39] Mannucci, E., Ognibene, A., Cremasco, F., Bardini, G., Mencucci, A., Pierazzuoli, E., Ciani, S., Messeri, G. and Rotella, C.M. (2001) Effect of Metformin on Glucagon-Like Peptide 1 (GLP-1) and Leptin Levels in Obese Nondiabetic Subjects. Diabetes Care, 24, 489-494. https://doi.org/10.2337/diacare.24.3.489

[40] Green, B.D., Irwin, N., Duffy, N.A., Gault, V.A., O'harte, F.P.M. and Flatt, P.R. (2006) Inhibition of Dipeptidyl Peptidase-IV Activity by Metformin Enhances the Antidiabetic Effects of Glucagon-Like Peptide-1. European Journal of Pharmacology, 547, 192-199. https://doi.org/10.1016/j.ejphar.2006.07.043

[41] Mulherin, A.J., Oh, A.H., Kim, H., Grieco, A., Lauffer, L.M. and Brubaker, P.L. (2011) Mechanisms Underlying Metformin-Induced Secretion of Glucagon-Like Peptide-1 from the Intestinal L Cell. Endocrinology, 152, 4610-4619. https://doi.org/10.1210/en.2011-1485

[42] Eshghi, S.R.T., Bell, G.J. and Boulé, N.G. (2013) Effects of Aerobic Exercise with or without Metformin on Plasma Incretins in Type 2 Diabetes. Canadian Journal of Diabetes, 37, 375-380. https://doi.org/10.1016/j.jcjd.2013.07.030

[43] Wu, T., Thazhath, S.S., Bound, M.J., Jones, K.L., Horowitz, M. and Rayner, C.K. (2014) Mechanism of Increase in Plasma Intact GLP-1 by Metformin in Type 2 Diabetes: Stimulation of GLP-1 Secretion or Reduction in Plasma DPP-4 Activity? Diabetes Research and Clinical Practice, 106, e3-e6.

https://doi.org/10.1016/j.diabres.2014.08.004

[44] Bahne, E., Hansen, M., Brønden, A., Sonne, D.P., Vilsbøll, T. and Knop F.K. (2016) Involvement of Glucagon-Like Peptide-1 in the Glucose-Lowering Effect of Metformin. Diabetes, Obesity and Metabolism, 18, 955-961.

https://doi.org/10.1111/dom.12697

[45] Capozzi, M.E., DiMarchi, R.D., Tschöp, M.H., Finan, B. and Campbell, J.E. (2018) Targeting the Incretin/Glucagon System with Triagonists to Treat Diabetes. Endocrine Reviews, 39, 719-738. https://doi.org/10.1210/er.2018-00117

[46] Nguyen, T., Gong, M., Wen, S., Yuan, X., Wang, C., Jin, J. and Zhou, L. (2020) The Mechanism of Metabolic Influences on the Endogenous GLP-1 by Oral Antidiabetic Medications in Type 2 Diabetes Mellitus. Journal of Diabetes Research, 2020, Article ID: 4727390 . https://doi.org/10.1155/2020/4727390

[47] Alsalim, W., Göransson, O., Tura, A., Pacini, G., Mari, A. and Ahrén, Bo. (2020) Persistent Whole Day Meal Effects of Three Dipeptidyl Peptidase-4 Inhibitors on Glycaemia and Hormonal Responses in Metformin-Treated Type 2 Diabetes. Diabetes, Obesity and Metabolism, 22, 590-598. https://doi.org/10.1111/dom.13934 
[48] Lonovics, J., Devitt, P., Watson, L.C., Rayford, P.L. and Thompson, J.C. (1981) Pancreatic Polypeptide. A Review. Archives of Surgery, 116, 1256-1264. https://doi.org/10.1001/archsurg.1981.01380220010002

[49] Valicherla, G.R., Hossain, Z., Mahata, S.K. and Gayen, J.R. (2013) Pancreastatin Is an Endogenous Peptide That Regulates Glucose Homeostasis. Physiological Genomics, 45, 1060-1071. https://doi.org/10.1152/physiolgenomics.00131.2013

[50] Westermark, P., Andersson, A. and Westermark, G.T. (2011) Islet Amyloid Polypeptide, Islet Amyloid, and Diabetes Mellitus. Physiological Reviews, 91, 795-826. https://doi.org/10.1152/physrev.00042.2009

[51] Yadav, D., Nair, S., Norkus, E.P. and Pitchumoni, C.S. (2000) Non Specific Hyperamylasemia and Hyperlipasemia in Diabetic Ketoacidosis: Incidence and Correlation with Biochemical Abnormalities. American Journal of Gastroenterology, 95, 3123-3128.

[52] Quiros, J.A., Marcin, J.P., Kuppermann, N., Nasrollahzadeh, F., Rewers, A., DiCarlo, J., Neely, E.K. and Glaser, N. (2008) Elevated Serum Amylase and Lipase in Pediatric Diabetic Ketoacidosis. Pediatric Critical Care Medicine, 9, 418-422.

https://doi.org/10.1097/PCC.0b013e318172e99b

[53] Campbell-Thompson, M., Rodriguez-Calvo, T. and Battaglia, M. (2015) Abnormalities of the Exocrine Pancreas in Type 1 Diabetes. Current Diabetes Reports, 15, Article No. 79. https://doi.org/10.1007/s11892-015-0653-y

[54] Mohapatra, S., Majumder, S., Smyrk, T.C., Zhang, L., Matveyenko, A., Kudva, Y.C. and Chari, S.T. (2016) Diabetes Mellitus Is Associated With an Exocrine Pancreatopathy: Conclusions From a Review of Literature. Pancreas, 45, 1104-1110. https://doi.org/10.1097/MPA.0000000000000609

[55] Larger, E., Philippe, M.F., Barbot-Trystram, L., Radu, A., Rotariu, M., Nobécourt, E. and Boitard, C. (2012) Pancreatic Exocrine Function in Patients with Diabetes. Diabetic Medicine, 29, 1047-1054. https://doi.org/10.1111/j.1464-5491.2012.03597.x

[56] Radlinger, B., Ramoser, G. and Kaser, S. (2020) Exocrine Pancreatic Insufficiency in Type 1 and Type 2 Diabetes. Current Diabetes Reports, 20, Article No. 18. https://doi.org/10.1007/s11892-020-01304-0

[57] Tilg, H., Moschen, A.R. and Roden, M. (2017) NAFLD and Diabetes Mellitus. Nature Reviews Gastroenterology \& Hepatology, 14, 32-42. https://doi.org/10.1038/nrgastro.2016.147

[58] Radaelli, M.G., Martucci, F., Perra, S., Accornero, S., Castoldi, G., Lattuada, G., Manzoni, G. and Perseghin, G. (2018) NAFLD/NASH in Patients with Type 2 Diabetes and Related Treatment Options. Journal of Endocrinological Investigation, 41, 509-521. https://doi.org/10.1007/s40618-017-0799-3

[59] Younossi, Z.M., Tampi, R.P., Racila, A., Qiu, Y., Burns, L., Younossi, I. and Nader, F. (2020) Economic and Clinical Burden of Nonalcoholic Steatohepatitis in Patients With Type 2 Diabetes in the U.S.. Diabetes Care, 43, 283-289. https://doi.org/10.2337/dc19-1113

[60] Taskinen, M.R. and Borén, J. (2015) New Insights into the Pathophysiology of Dyslipidemia in Type 2 Diabetes. Atherosclerosis, 239, 483-495. https://doi.org/10.1016/j.atherosclerosis.2015.01.039

[61] Bulut, T., Demirel, F. and Metin, A. (2017) The Prevalence of Dyslipidemia and Associated Factors in Children and Adolescents with Type 1 Diabetes. Journal of Pediatric Endocrinology and Metabolism, 30, 181-187.

https://doi.org/10.1515/jpem-2016-0111

[62] Athyros, V.G., Doumas, M., Imprialos, K.P., Stavropoulos, K., Georgianou, E., Kat- 
simardou, A. and Karagiannis, A. (2018) Diabetes and Lipid Metabolism. Hormones, 17, 61-67. https://doi.org/10.1007/s42000-018-0014-8

[63] Shahwan, M.J., Jairoun, A.A., Farajallah, A. and Shanabli, S. (2019) Prevalence of Dyslipidemia and Factors Affecting Lipid Profile in Patients with Type 2 Diabetes. Diabetology \& Metabolic Syndrome, 13, 2387-2392.

https://doi.org/10.1016/j.dsx.2019.06.009

[64] Sobczak, A.I.S., Blindauer, C.A. and Stewart, A.J. (2019) Changes in Plasma Free Fatty Acids Associated with Type-2 Diabetes. Nutrients, 11, 2022. https://doi.org/10.3390/nu11092022

[65] Lazarte, J. and Hegele, R.A. (2020) Dyslipidemia Management in Adults with Diabetes. Canadian Journal of Diabetes, 44, 53-60.

https://doi.org/10.1016/j.jcjd.2019.07.003

[66] Knebel, B., Strassburger, K., Szendroedi, J., Kotzka, J., Scheer, M., Nowotny, B., Müssig, K., Lehr, S., Pacini, G., Finner, H., Klüppelholz, B., Giani, G., Al-Hasani, H. and Roden, M., for the German Diabetes Study Group (2016) Specific Metabolic Profiles and Their Relationship to Insulin Resistance in Recent-Onset Type 1 and Type 2 Diabetes. The Journal of Clinical Endocrinology \& Metabolism, 101, 2130-2140. https://doi.org/10.1210/jc.2015-4133

[67] Derosa, G., Mugellini, A., Ciccarelli, L., Crescenzi, G. and Fogari, R. (2003) Comparison between Repaglinide and Glimepiride in Patients with Type 2 Diabetes Mellitus: A One-Year, Randomized, Double-Blind Assessment of Metabolic Parameters and Cardiovascular Risk Factors. Clinical Therapeutics, 25, 472-484. https://doi.org/10.1016/S0149-2918(03)80090-5

[68] Kabadi, U.M. and Kabadi, M.U. (2001) Improvement in Lipids with Glimepiride in Type 2 Diabetes Mellitus. Journal of Diabetes Research, 35, 155.

[69] Esmail, R. and Kabadi, U.M. (2016) Improvement in Cardiovascular Risk Markers with Glimepiride in Non Obese Subjects with Pre Diabetes: Similar to Obese Cohort Treated with Metformin. British Journal of Medicine \& Medical Research, 18, 1-6.

[70] Calle, M.C. and Fernandez, M.L. (2012) Inflammation and Type 2 Diabetes. Diabetes \& Metabolism, 38, 183-191. https://doi.org/10.1016/j.diabet.2011.11.006

[71] Stefan, N. and Haring, H. (2013) The Role of Hepatokines in Metabolism. Nature Reviews Endocrinology, 9, 144-152. https://doi.org/10.1038/nrendo.2012.258

[72] Hansen, J.S., Pedersen, B.K., Xu, G., Lehmann, R., Weigert, C. and Plomgaard, P. (2016) Exercise-Induced Secretion of FGF21 and Follistatin Are Blocked by Pancreatic Clamp and Impaired in Type 2 Diabetes. The Journal of Clinical Endocrinology \& Metabolism, 101, 2816-2825. https://doi.org/10.1210/jc.2016-1681

[73] Shruthi, S., Mohan, V., Amutha, A. and Aravindhan, V. (2016) Increased Serum Levels of Novel T Cell Cytokines IL-33, IL-9 and IL-17 in Subjects with Type-1 Diabetes. Cytokine, 86, 6-9. https://doi.org/10.1016/j.cyto.2016.07.007

[74] Brahimaj, A., Ligthart, S., Ghanbari, M., Ikram, M.A., Hofman, A., Franco, O.H., Kavousi, M. and Dehghan, A. (2017) Novel Inflammatory Markers for Incident Pre-Diabetes and Type 2 Diabetes: The Rotterdam Study. European Journal of Epidemiology, 32, 217-226. https://doi.org/10.1007/s10654-017-0236-0

[75] Reinehr, T. and Roth, C.L. (2018) Inflammation Markers in Type 2 Diabetes and the Metabolic Syndrome in the Pediatric Population. Current Diabetes Reports, 18, Article No. 131. https://doi.org/10.1007/s11892-018-1110-5

[76] Borzouei, S., Sheikh, V., Ghasemi, M., Zamani, A., Telikani, Z., Zareighane, Z., Salehi, I., Mozayanimonfared, A., Amirzargar, M.A. and Alahgholi-Hajibehzad, M. (2019) Anti-Inflammatory Effect of Combined Sitagliptin and Vitamin D3 on Cyto- 
kines Profile in Patients with Type 2 Diabetes Mellitus. Journal of Interferon \& Cytokine Research, 39, 293-301. https://doi.org/10.1089/jir.2018.0144

[77] Mazidi, M., Karimi, E., Rezaie, P. and Ferns, G.A. (2017) Treatment with GLP1 Receptor Agonists Reduce Serum CRP Concentrations in Patients with Type 2 Diabetes Mellitus: A Systematic Review and Meta-Analysis of Randomized Controlled Trials. Journal of Diabetes and its Complications, 31, 1237-1242. https://doi.org/10.1016/j.jdiacomp.2016.05.022

[78] Zóka, A. Barna, G., Hadarits, O., Al-Aissa, Z., Wichmann, B., Műzes, G., Somogyi, A. and Firneisz, G. (2015) Altered Crosstalk in the Dipeptidyl Peptidase-4-IncretinImmune System in Type 1 Diabetes: A Hypothesis Generating Pilot Study. Human Immunology, 76, 667-672. https://doi.org/10.1016/j.humimm.2015.09.018

[79] Karbalaee-Hasani, A., Khadive, T., Eskandari, M., Shahidi, S., Mosavi, M., Nejadebrahimi, Z., Khalkhali, L., Sangdari, A., Mohammadi, D., Soltani, A., Khodabandehloo, H., Hosseini, H. and Koushki, M. (2021) Effect of Metformin on Circulating Levels of Inflammatory Markers in Patients with Type 2 Diabetes: A Systematic Review and Meta-Analysis of Randomized Controlled Trials. Annals of Pharmacotherapy. https://doi.org/10.1177/1060028020985303

[80] Kershaw, E.E. and Flier, J.S. (2004) Adipose Tissue as an Endocrine Organ. Journal of Clinical Endocrinology \& Metabolism, 89, 2548-2556.

https://doi.org/10.1210/jc.2004-0395

[81] Fasshauer, M. and Blüher, M. (2015) Adipokines in Health and Disease. Trends in Pharmacological Sciences, 36, 461-470. https://doi.org/10.1016/j.tips.2015.04.014

[82] López-Jaramillo, P., Gómez-Arbeláez, D., López-López, J., López-López, C., MartínezOrtega, J., Gómez-Rodríguez, A. and Triana-Cubillos, S. (2014) The Role of Leptin/Adiponectin Ratio in Metabolic Syndrome and Diabetes. Hormone Molecular Biology and Clinical Investigation, 18, 37-45. https://doi.org/10.1515/hmbci-2013-0053

[83] Lau, W.B., Ohashi, K., Wang, Y., Ogawa, H., Murohara, T., Ma, X.L. and Ouchi, N. (2017) Role of Adipokines in Cardiovascular Disease. Circulation Journal, 81, 920-928.

[84] Baldauff, N.H., Tfayli, H., Dong, W., et al. (2016) Relationship of Adiponectin and Leptin with Autoimmunity in Children with New-Onset Type 1 Diabetes: A Pilot Study. Pediatric Diabetes, 17, 249-256. https://doi.org/10.1111/pedi.12267

[85] Leth, H., Andersen, K.K., Frystyk, J., Tarnow, L., Rossing, P., Parving, H.H. and Flyvbjerg, A. (2008) Elevated Levels of High-Molecular-Weight Adiponectin in Type 1 Diabetes. The Journal of Clinical Endocrinology \& Metabolism, 93, 3186-3191. https://doi.org/10.1210/jc.2008-0360

[86] Kumar, S., Hossain, J., Nader, N., Aguirre, R., Sriram, S. and Balagopal, B.P. (2016) Decreased Circulating Levels of Spexin in Obese Children. The Journal of Clinical Endocrinology \& Metabolism, 101, 2931-2936.

https://doi.org/10.1210/jc.2016-1177

[87] Elbert, T., Gebhardt, C., Scholz, M., et al. (2018) Relationship between 12 Adipocytokines and Distinct Components of Metabolic Syndrome. The Journal of Clinical Endocrinology \& Metabolism, 103, 1015-1023.

https://doi.org/10.1210/jc.2017-02085

[88] Yin, C.Y., Hu, W., Wang M. and Xiao, Y.F. (2019) The Role of the Adipocytokines Vaspin and Visfatin in Vascular Endothelial Function and Insulin Resistance in Obese Children. BMC Endocrine Disorders, 19, 127. https://doi.org/10.1186/s12902-019-0452-6

[89] Perez-Sotelo, D., Roca-Rivada, A., Larrosa-Garcia, M., Castelao, C., Baamonde, I., 
Baltar, J., Crujeiras, A.B., Seoane, L.M., Casanueva, F.F. and Pardo, M. (2017) Visceral and Subcutaneous Adipose Tissue Express and Secrete Functional Alpha2hsglycoprotein (Fetuin a) Especially in Obesity. Endocrine, 55, 435-446. https://doi.org/10.1007/s12020-016-1132-1

[90] Jiala, I., Devaraj, S., Bettaieb, A., Haj, F. and Adams-Huet, B. (2015) Increased Adipose Tissue Secretion of Fetuin-A, Lipopolysaccharide-Binding Protein and HighMobility Group Box Protein 1 in Metabolic Syndrome. Atherosclerosis, 241, 130 137. https://doi.org/10.1016/j.atherosclerosis.2015.04.814

[91] Liu, S., Hu, W., He, Y., Li, L., Liu, H., Gao, L., Yang G. and Liao, X. (2020) Serum Fetuin-A Levels Are Increased and Associated with Insulin Resistance in Women with Polycystic Ovary Syndrome. BMC Endocrine Disorders, 20, Article No. 67. https://doi.org/10.1186/s12902-020-0538-1

[92] Liang, W. and Ye, D.D. (2019) The Potential of Adipokines as Biomarkers and Therapeutic Agents for Vascular Complications in Type 2 Diabetes Mellitus. Cytokine \& Growth Factor Reviews, 48, 32-39. https://doi.org/10.1016/j.cytogfr.2019.06.002

[93] Heliövaara, M.K., Teppo, A.M., Karonen, S.L., Tuominen, J.A. and Ebeling, P. (2006) Improved Glycaemia in Type 1 Diabetes Results in Decreased Levels of Soluble Adhesion Molecules with No Change in Serum Adiponectin or Most Acute Phase Proteins. Experimental and Clinical Endocrinology \& Diabetes, 114, 295-300. https://doi.org/10.1055/s-2006-924265

[94] Galler, A., Gelbrich, G., Kratzsch, J., Noack, N., Kapellen, T. and Kiess, W. (2007) Elevated Serum Levels of Adiponectin in Children, Adolescents and Young Adults with Type 1 Diabetes and the Impact of Age, Gender, Body Mass Index and Metabolic Control: A Longitudinal Study. European Journal of Endocrinology, 157, 481489. https://doi.org/10.1530/EJE-07-0250

[95] Tsunekawa, T., Hayashi, T., Suzuki, Y., Matsui-Hirai, H., Kano, H., Fukatsu, A., Nomura, N., Miyazaki, A. and Iguchi, A. (2003) Plasma Adiponectin Plays an Important Role in Improving Insulin Resistance with Glimepiride in Elderly Type 2 Diabetic Subjects. Diabetes Care, 26, 285-289.

https://doi.org/10.2337/diacare.26.2.285

[96] Alba-Loureiro, T.C., Munhoz, C.D., Martins, J.O., Cerchiaro, G.A., Scavone, C., Curi, R. and Sannomiya, P. (2007) Neutrophil Function and Metabolism in Individuals with Diabetes Mellitus. Brazilian Journal of Medical and Biological Research, 40, 1037-1044. https://doi.org/10.1590/S0100-879X2006005000143

[97] Hanley, A.J., Retnakaran, R., Qi, Y., Gerstein, H.C., Perkins, B., Raboud, J., Harris, S.B. and Zinman, B. (2009) Association of Hematological Parameters with Insulin Resistance and Beta-Cell Dysfunction in Nondiabetic Subjects. The Journal of Clinical Endocrinology \& Metabolism, 94, 3824-3832. https://doi.org/10.1210/jc.2009-0719

[98] Rao, X., Zhong, J. and Sun, Q. (2014) The Heterogenic Properties of Monocytes/Macrophages and Neutrophils in Inflammatory Response in Diabetes. Life Sciences, 116, 59-66. https://doi.org/10.1016/j.lfs.2014.09.015

[99] Menegazzo, L., Ciciliot, S., Poncina, N., Mazzucato, M., Persano, M., Bonora, B., Albiero, M., Kreutzenberg, V.S., Avogaro, A. and Fadini, G.P. (2015) NETosis Is Induced by High Glucose and Associated with Type 2 Diabetes. Acta Diabetologica, 52, 497-503. https://doi.org/10.1007/s00592-014-0676-X

[100] Kolseth, I.B., Reine, T.M., Parker, K., Sudworth, A., Witczak, B.J., Jenssen, T.G. and Kolset, S.O. (2017) Increased Levels of Inflammatory Mediators and Proinflammatory Monocytes in Patients with Type I Diabetes Mellitus and Nephropathy. Journal of 
Diabetes and its Complications, 31, 245-252.

https://doi.org/10.1016/j.jdiacomp.2016.06.029

[101] Szablewski, L. and Sulima, A. (2017) The Structural and Functional Changes of Blood Cells and Molecular Components in Diabetes Mellitus. Journal of Biological Chemistry, 398, 411-423. https://doi.org/10.1515/hsz-2016-0196

[102] Gajos, G., Siniarski, A., Natorska, J., Ząbczyk, M., Siudut, J., Malinowski, K.P., Gołębiowska-Wiatrak, R., Rostoff, P. and Undas, A. (2018) Polyhedrocytes in Blood Clots of Type 2 Diabetic Patients with High Cardiovascular Risk: Association with Glycemia, Oxidative Stress and Platelet Activation. Cardiovascular Diabetology, 17, 146. https://doi.org/10.1186/s12933-018-0789-6

[103] Nagalievska, M., Sabadashka, M., Hachkova, H. and Sybirna, N. (2018) Galega Officinalis Extract Regulate the Diabetes Mellitus Related Violations of Proliferation, Functions and Apoptosis of Leukocytes. BMC Complementary Medicine and Therapies, 18, Article No. 4. https://doi.org/10.1186/s12906-017-2079-3

[104] Eastman, D.K., Bottenberg, M.M., Hegge, K.A., Ourth, H. and Kabadi, U. (2009) Intensive Insulin Therapy in Critical Care Settings. Current Clinical Pharmacology, 4, 71-77. https://doi.org/10.2174/157488409787236100

[105] Picard, F., Adjedj, J. and Varenne, O. (2017) Diabetes Mellitus, a Prothrombotic Disease. Annales de Cardiologie et d' Angéiologie, 66, 385-392. https://doi.org/10.1016/j.ancard.2017.10.011

[106] Li, Q., Li, L. and Li, Y. (2015) Enhanced RBC Aggregation in Type 2 Diabetes Patients. Journal of Clinical Laboratory Analysis, 29, 387-389. https://doi.org/10.1002/jcla.21784

[107] Vasquez, B.Y., Vázquez, M.A., Jáquez, M.G., Huemoeller, A.H., Intaglietta, M. and Cabrales, P. (2010) Blood Pressure Directly Correlates with Blood Viscosity in Diabetes Type 1 Children but Not in Normals. Clinical Hemorheology and Microcirculation, 44, 55-61. https://doi.org/10.3233/CH-2010-1252

[108] Irace, C., Carallo, C., Scavelli, F., Franceschi, M.S., Esposito, T. and Gnasso, A. (2014) Blood Viscosity in Subjects with Normoglycemia and Prediabetes. Diabetes Care, 37, 488-492. https://doi.org/10.2337/dc13-1374

[109] Mazhara, M., Muhammada, A.M. and Uh-Hyunb, K. (2019) Hyperglycemia Associated Blood Viscosity Can Be a Nexus Stimuli. Clinical Hemorheology and Microcirculation, 71, 103-112. https://doi.org/10.3233/CH-180426

[110] Andreassen, C.S., Jensen, J.M., Jakobsen, J., Ulhøj, B.P. and Andersen, H. (2014) Striated Muscle Fiber Size, Composition, and Capillary Density in Diabetes in Relation to Neuropathy and Muscle Strength. Journal of Diabetes, 6, 462-471. https://doi.org/10.1111/1753-0407.12124

[111] Diaz-Morales, N., Rovira-Llopis, S., Escribano-Lopez, I., Bañuls, C., Lopez-Domenech, S., Falcón, R., de Maranon, A.M., Sola, E., Jover, A., Roldan, I., Diez, J.L., Rocha, M., Hernández-Mijares, A. and Víctor, V.M. (2016) Role of Oxidative Stress and Mitochondrial Dysfunction in Skeletal Muscle in Type 2 Diabetic Patients. Current Pharmaceutical Design, 22, 2650-2656. https://doi.org/10.2174/1381612822666160217142949

[112] Ławnicki, J., Hansdorfer-Korzon, R. and Myśliwiec, M. (2019) Alterations in Postural Control, Gait Pattern, and Muscle Function in Diabetes Mellitus: Does It Matter in Children and Adolescents with Type 1 Diabetes? Pediatric Endocrinology Diabetes and Metabolism, 25, 23-27. https://doi.org/10.5114/pedm.2019.84707

[113] Orlando, G., Balducci, S., Bazzucchi, I., Pugliese, G. and Sacchetti, M. (2016) Neuromuscular Dysfunction in Type 2 Diabetes: Underlying Mechanisms and Effect of 
Resistance Training. Diabetes/Metabolism Research and Reviews, 32, 40-50. https://doi.org/10.1002/dmrr.2658

[114] Orlando, G., Balducci, S., Bazzucchi, I., Pugliese, G. and Sacchetti, M. (2017) Muscle Fatigability in Type 2 Diabetes. Diabetes/Metabolism Research and Reviews, 33, e2821. https://doi.org/10.1002/dmrr.2821

[115] Garneau, L. and Aguer, C. (2019) Role of Myokines in the Development of Skeletal Muscle Insulin Resistance and Related Metabolic Defects in Type 2 Diabetes. Diabetes \& Metabolism, 45, 505-516. https://doi.org/10.1016/j.diabet.2019.02.006

[116] Min, Y.W., Ko, E.J., Lee, J.Y. and Rhee, P.L. (2018) Impaired Neural Pathway in Gastric Muscles of Patients with Diabetes. Scientific Reports, 8, Article No. 7101. https://doi.org/10.1038/s41598-018-24147-y

[117] Montero, D., Walther, G., Pérez-Martin, A., Vicente-Salar, N., Roche, E. and Vinet, A. (2013) Vascular Smooth Muscle Function in Type 2 Diabetes Mellitus: A Systematic Review and Meta-Analysis. Diabetologia, 56, 2122-2133. https://doi.org/10.1007/s00125-013-2974-1

[118] Doyon, G. and Bruemmer, D. (2016) Vascular Smooth Muscle Cell Dysfunction in Diabetes: Nuclear Receptors Channel to Relaxation. Clinical Science, 130, 1837-1839. https://doi.org/10.1042/CS20160518

[119] Hadi, H.E., Vettor, R. and Rossato, M. (2019) Cardiomyocyte Mitochondrial Dysfunction in Diabetes and Its Contribution in Cardiac Arrhythmogenesis. Mitochondrion, 46, 6-14. https://doi.org/10.1016/j.mito.2019.03.005

[120] Kinney, G.L., Black-Shinn, J.L., Wan, E.S., Make, B., Regan, E., Lutz, S., Soler, X., Silverman, E.K., Crapo, J., Hokanson, J.E. and the COPDGene Investigators (2014) Pulmonary Function Reduction in Diabetes with and without Chronic Obstructive Pulmonary Disease. Diabetes Care, 37, 389-395. https://doi.org/10.2337/dc13-1435

[121] Martín-Frías, M., Lamas, A., Lara, E., Alonso, M., Ros, P., Barrio, R. (2015) Pulmonary Function in Children with Type 1 Diabetes Mellitus. Journal of Pediatric Endocrinology and Metabolism, 28, 163-169. https://doi.org/10.1515/jpem-2014-0147

[122] Röhling, M., Pesta, D., Markgraf, D.F., Strassburger, K., Knebel, B., Burkart, V., Szendroedi, J., Müssig, K., Roden, M. and GDS Study Group (2018) Metabolic Determinants of Impaired Pulmonary Function in Patients with Newly Diagnosed Type 2 Diabetes Mellitus. Experimental and Clinical Endocrinology \& Diabetes, 126, 584589. https://doi.org/10.1055/a-0653-7135

[123] Kuziemski, K., Słomiński, W. and Jassem, E. (2019) Impact of Diabetes Mellitus on Functional Exercise Capacity and Pulmonary Functions in Patients with Diabetes and Healthy Persons. BMC Endocrine Disorders, 19, Article No. 2. https://doi.org/10.1186/s12902-018-0328-1

[124] Epstein, S., Defeudis, G., Manfrini, S., Napoli, N. and Pozzilli, P. (2016) Scientific Committee of the First International Symposium on Diabetes and Bone. Diabetes and Disordered Bone Metabolism (Diabetic Osteodystrophy): Time for Recognition. Osteoporosis International, 27, 1931-1951.https://doi.org/10.1007/s00198-015-3454-X

[125] Keenan, H.A., Maddaloni, E. (2016) Bone Microarchitecture in Type 1 Diabetes: It Is Complicated. Current Osteoporosis Reports, 14, 351-358. https://doi.org/10.1007/s11914-016-0338-8

[126] Kanazawa, P. and Sugimoto, T. (2018) Diabetes Mellitus-Induced Bone Fragility. Journal of Internal Medicine, 57, 2773-2785. https://doi.org/10.2169/internalmedicine.0905-18

[127] Shanbhogue, V.V., Hansen, S., Frost, M., Brixen, K. and Hermann, A.P. (2017) Bone Disease in Diabetes: Another Manifestation of Microvascular Disease? The Lancet 
Diabetes \& Endocrinology, 5, 827-838. https://doi.org/10.1016/S2213-8587(17)30134-1

[128] Shah, V.N., Carpenter, R.D., Ferguson, V.L. and Schwartz, A.V. (2018) Bone Health in Type 1 Diabetes. Current Opinion in Endocrinology \& Diabetes and Obesity, 25, 231-236. https://doi.org/10.1097/MED.0000000000000421

[129] Paschou, S.A., Dede, A.D., Anagnostis, P.G., Vryonidou, A., Morganstein, D. and Goulis, D.G. (2017) Type 2 Diabetes and Osteoporosis: A Guide to Optimal Management. The Journal of Clinical Endocrinology \& Metabolism, 102, 3621-3634. https://doi.org/10.1210/jc.2017-00042

[130] Rozas-Moreno, P., Reyes-García, R., Jódar-Gimeno, E., Varsavsky, M., Luque-Fernández, I., Cortés-Berdonces, M., Muñoz-Torres, M. (2017) Recommendations on the Effect of Antidiabetic Drugs in Bone. Endocrinología, Diabetes y Nutrición, 64, 1-6. https://doi.org/10.1016/j.endinu.2016.11.001

[131] Kheniser, K.G., Santos, C.M.P. and Kashyap, S.R. (2018) The Effects of Diabetes Therapy on Bone: A Clinical Perspective. Journal of Diabetes and Its Complications, 32, 713-719. https://doi.org/10.1016/j.jdiacomp.2018.04.005

[132] Bahrambeigi, S., Yousefi, B., Rahimi, M. and Shafiei-Irannejad, V. (2019) Metformin; An Old Antidiabetic Drug with New Potentials in Bone Disorders. Biomedicine \& Pharmacotherapy, 109, 1593-1601. https://doi.org/10.1016/j.biopha.2018.11.032

[133] Pietschmann, P., Schernthaner, G., Stephenson, J., Lang, I. and Templ, H. (1991) Enhanced Growth Hormone Responses to Growth Hormone Releasing Hormone in Male Type I Diabetic Patients. Hormone and Metabolic Research, 23, 379-382. https://doi.org/10.1055/s-2007-1003705

[134] Trümper, B.G., Reschke, K. and Molling, J. (1995) Circadian Variation of Insulin Requirement in Insulin Dependent Diabetes Mellitus the Relationship between Circadian Change in Insulin Demand and Diurnal Patterns of Growth Hormone, Cortisol and Glucagon during Euglycemia. Hormone and Metabolic Research, 27, 141-147. https://doi.org/10.1055/s-2007-979926

[135] Campbell, P.J., Bolli, G.B., Cryer, P.E. and Gerich, J.E. (1985) Pathogenesis of the Dawn Phenomenon in Patients with Insulin-Dependent Diabetes Mellitus. Accelerated Glucose Production and Impaired Glucose Utilization due to Nocturnal Surges in Growth Hormone Secretion. The New England Journal of Medicine, 312, 1473-1479. https://doi.org/10.1056/NEJM198506063122302

[136] Jenni, S., Christ, E.R. and Stettler, C. (2010) Exercise-Induced Growth Hormone Response in Euglycaemia and Hyperglycaemia in Patients with Type 1 Diabetes Mellitus. Diabetic Medicine, 27, 230-233. https://doi.org/10.1111/j.1464-5491.2009.02893.x

[137] Nambam, B. and Schatz, D. (2018) Growth Hormone and Insulin-Like Growth Factor-I Axis in Type 1 Diabetes. Growth Hormone \& IGF Research, 38, 49-52. https://doi.org/10.1016/j.ghir.2017.12.005

[138] Joseph, J.J. and Golden, S.H. (2016) Cortisol Dysregulation: The Bidirectional Link between Stress, Depression, and Type 2 Diabetes Mellitus. Annals of the New York Academy of Sciences, 1391, 20-34. https://doi.org/10.1111/nyas.13217

[139] Raff, H. and Magill, S.B. (2016) Is the Hypothalamic-Pituitary-Adrenal Axis Disrupted in Type 2 Diabetes Mellitus? Endocrine, 54, 273-275. https://doi.org/10.1007/s12020-016-1108-1

[140] Tirabassi, G., Corona, G., Lamonica, G.R., Lenzi, A., Maggi, M. and Balercia, G. (2016) Diabetes Mellitus-Associated Functional Hypercortisolism Impairs Sexual Function in Male Late-Onset Hypogonadism. Hormone and Metabolic Research, 48, 48-53. https://doi.org/10.1055/s-0035-1548870 
[141] Maresch, C.C., Stute, D.C., Alves, M.G., Oliveira, P.F., de Kretser, D.M. and Linn, T. (2018) Diabetes-Induced Hyperglycemia Impairs Male Reproductive Function: A Systematic Review. Human Reproduction Update, 24, 86-105. https://doi.org/10.1093/humupd/dmx033

[142] Vignera, L.S., Condorelli, R.A., Mauro, D.M., Presti, L.D., Mongioì, L.M., Russo, G. and Calogero, A.E. (2015) Reproductive Function in Male Patients with Type 1 Diabetes Mellitus. Andrology, 3, 1082-1087. https://doi.org/10.1111/andr.12097

[143] Kabadi, U.M. (1986) Serum T3 and Reverse T3 Concentrations: Indices of Metabolic Control in Diabetes Mellitus. Diabetes Research, 3, 417-421.

[144] Kabadi, U.M. (1984) Altered Thyrotropin Secretion in Uncontrolled Type II Diabetes Mellitus and Its Normalization on Attainment of Eumetabolic State. The Journal of Clinical Endocrinology \& Metabolism, 59, 521-525. https://doi.org/10.1210/jcem-59-3-521

[145] Schnack, C. and Schernthaner, G. (1987) Pituitary Thyrotroph Function and Thyroid Hormones in Longstanding Type-II Diabetes Mellitus before and after Insulin Treatment. Experimental and Clinical Endocrinology \& Diabetes, 90, 243-248. https://doi.org/10.1055/s-0029-1210696

[146] Custro, N., Scafidi, V. and Borsellino, T. (1991) Changes in the Thyroid Hormone Picture That May Be Found in Severely Decompensated Type II Diabetics. Minerva Medica, 82, 9-14.

[147] Sharma, S. and Kabadi, U.M. (2008) Euthyroid Sick Syndrome. Primary Care Reports, 14, 1-12.

[148] Orlická, E., Vondra, K., Hill, M., Skibová, J., Sterzl, I. and Zamrazil, V. (2008) TRH Test in Patients with Diabetes Mellitus Type 1 and/or Autoimmune Thyroiditis. Changes in the Pituitary-Thyroid Axis, Reverse T3, Prolactin and Growth Hormone Levels. Physiological Research, 57, S109-S117.

[149] Neto, A.M., Parisi, M.C.R., Tambascia, M.A., Alegre, S.M., Pavin, E.J. and ZantutWittmann, D.E. (2013) The Influence of Body Mass Index and Low-Grade Systemic Inflammation on Thyroid Hormone Abnormalities in Patients with Type 2 Diabetes. Endocrine Journal, 60, 877-884.

[150] Kouidhi, S., Berhouma, R., Ammar, M., Rouissi, K., Jarboui, S., Clerget-Froidevaux, M.S., Seugnet, I., Abid, H., Bchir, F., Demeneix, B., Guissouma, H. and Elgaaied, A.B. (2013) Relationship of Thyroid Function with Obesity and Type 2 Diabetes in Euthyroid Tunisian Subjects. Endocrine Research, 38, 15-23. https://doi.org/10.3109/07435800.2012.699987

[151] Liu, F., Di, J., Yu, H., Han, J., Bao, Y. and Jia, W. (2017) Effect of Roux-en-Y Gastric Bypass on Thyroid Function in Euthyroid Patients with Obesity and Type 2 Diabetes. Surgery for Obesity and Related Diseases, 13, 1701-1707. https://doi.org/10.1016/j.soard.2017.06.001

[152] Mirboluk, A.A., Rohani, F., Asadi, R. and Eslamian, M.R. (2017) Thyroid Function Test in Diabetic Ketoacidosis. Diabetes \& Metabolic Syndrome: Clinical Research \& Reviews, 11, S623-S625. https://doi.org/10.1016/j.dsx.2017.04.015

[153] Qin, K., Zhang, F., Wu, Q., Liu, Z., Huang, Y., Tan, J., Zhou, Y., An, Z., Li, S. and Li, S. (2020) Thyroid Hormone Changes in Euthyroid Patients with Diabetes. Diabetes, Metabolic Syndrome and Obesity: Targets and Therapy, 13, 2533-2540. https://doi.org/10.2147/DMSO.S260039

[154] Condorelli, R.A., Calogero, A.E., di Mauro, M., Mongioi', L.M., Cannarella, R., Rosta, G. and la Vignera, S. (2018) Androgen Excess and Metabolic Disorders in Women with PCOS: Beyond the Body Mass Index. Journal of Endocrinological Investigation, 
41, 383-388. https://doi.org/10.1007/s40618-017-0762-3

[155] Łagowska, K., Bajerska, J. and Jamka, M. (2018) The Role of Vitamin D Oral Supplementation in Insulin Resistance in Women with Polycystic Ovary Syndrome: A Systematic Review and Meta-Analysis of Randomized Controlled Trials. Nutrients, 10, 1637. https://doi.org/10.3390/nu10111637

[156] Wiweko, B., Indra, I., Susanto, C., Natadisastra, M. and Hestiantoro, A. (2018) The Correlation between Serum AMH and HOMA-IR among PCOS Phenotypes. BMC Research Notes, 11, Article No. 114. https://doi.org/10.1186/s13104-018-3207-y

[157] Alan, M., Gurlek, B., Yilmaz, A., Aksit, M., Aslanipour, B., Gulhan, I., Mehmet, C. and Taner, C.E. (2019) Asprosin: A Novel Peptide Hormone Related to Insulin Resistance in Women with Polycystic Ovary Syndrome. Gynecological Endocrinology, 35, 220-223. https://doi.org/10.1080/09513590.2018.1512967

[158] Zhang, D., Yang, X., Li, J., Yu, J. and Wu, X. (2019) Effect of Hyperinsulinaemia and Insulin Resistance on Endocrine, Metabolic and Fertility Outcomes in Women with Polycystic Ovary Syndrome Undergoing Ovulation Induction. Clinical Endocrinology, 91, 440-448. https://doi.org/10.1111/cen.14050

[159] Grossmann, M. (2018) Hypogonadism and Male Obesity: Focus on Unresolved Questions. Clinical Endocrinology, 89, 11-21. https://doi.org/10.1111/cen.13723

[160] Dhindsa, S., Ghanim, H., Batra, M. and Dandona, P. (2018) Hypogonadotropic Hypogonadism in Men with Diabesity. Diabetes Care, 41, 1516-1525. https://doi.org/10.2337/dc17-2510

[161] Molina-Vega, M., Muñoz-Garach, A., Damas-Fuentes, M., Fernández-García, J.C. and Tinahones, F.J. (2018) Secondary Male Hypogonadism: A Prevalent but Overlooked Comorbidity of Obesity. Asian Journal of Andrology, 20, 531-538. https://doi.org/10.4103/aja.aja 4418

[162] Giagulli, V.A., Castellana, M., Murro, I., Pelusi, C., Guastamacchia, E., Triggiani, V. and de Pergola, G. (2019) The Role of Diet and Weight Loss in Improving Secondary Hypogonadism in Men with Obesity with or without Type 2 Diabetes Mellitus. $\mathrm{Nu}$ trients , 11, 2975. https://doi.org/10.3390/nu11122975

[163] Rigon, F.A., Ronsoni, M.F., Hohl, A. and van de Sande-Lee, S. (2019) Effects of Bariatric Surgery in Male Obesity-Associated Hypogonadism. Obesity Surgery, 29, 2115 2125. https://doi.org/10.1007/s11695-019-03829-0

[164] Kabadi, U.M., Mehamood, H., Gilson, S. and Fox, I. (1995) Glycoslated Hemoglobin Concentration in Critical Illness. Journal of Diabetes Research, 28, 1-8.

[165] Kabadi, U.M. (1998) Hood: Increased Glycation of Hemoglobin in AIDS: Relation to Severity of the Disorder. Journal of Diabetes Research, 33, 37-44.

[166] Kabadi, U.M. (2008) Elevated Fructosamine in AIDS. Endocrine Practice, 14, 686-690. https://doi.org/10.4158/EP.14.6.686

[167] Kabadi, U.M., Reust, C., and Kabadi, M.U. (2000) Weight Gain, Improvement in Metabolic Profile and Immunogenicity with Insulin Administration in AIDS. AIDS Patient Care and STDs, 14, 575.

[168] Bahrambeigi, S. and Shafiei-Irannejad, V. (2020) Immune-Mediated Anti-Tumor Effects of Metformin; Targeting Metabolic Reprogramming of T Cells as a New Possible Mechanism for Anti-Cancer Effects of Metformin. Biochemical Pharmacology, 174, 113787. https://doi.org/10.1016/j.bcp.2019.113787

[169] Shafiei-Irannejad, V., Samadi, N., Salehi, R., Yousefi, B. and Zarghami, N. (2017) New Insights into Antidiabetic Drugs: Possible Applications in Cancer Treatment. Chemical Biology \& Drug Design, 90, 1056-1066. https://doi.org/10.1111/cbdd.13013 
[170] Bahrambeigi, S., Badalzadeh, R., Shafiei-Irannejad, V. and Alizadeh, A. (2019) Possible Protective Effects of Thiazolidinediones Antidiabetic Drugs in Colorectal Cancer. Critical Reviews ${ }^{\text {TM }}$ in Oncogenesis, 24, 251-258. https://doi.org/10.1615/CritRevOncog.2019031265

[171] Kabadi, U.M. and Kabadi, M.U. (2004) Weight Gain, Improvements in Metabolic Profiles and Immunogenicity with Insulin or Sulphonylurea Administration in AIDS. Clinical Drug Investigation, 24, 287-294. https://doi.org/10.2165/00044011-200424050-00005

[172] Eringa, E.C., Serne, E.H., Meijer, R.I., Schalkwijk, C.G., Houben, A.J., Stehouwer, C.D., Smulders, Y.M. and van Hinsbergh, V.W.M. (2013) Endothelial Dysfunction in (pre)Diabetes: Characteristics, Causative Mechanisms and Pathogenic Role in Type 2 Diabetes. Reviews in Endocrine and Metabolic Disorders, 14, 39-48. https://doi.org/10.1007/s11154-013-9239-7

[173] de Albuquerque do Nascimento, A.M.M., Sequeira, I.J., Vasconcelos, D.F., Gandolfi, L., Pratesi, R. and de Medeiros Nóbrega, Y.K. (2017) Endothelial Dysfunction in Children with Type 1 Diabetes Mellitusarch. Archives of Endocrinology and Metabolism, 61, 476-483. https://doi.org/10.1590/2359-3997000000271

[174] Goligorsky, M.S. (2017) Vascular Endothelium in Diabetes. American Journal of Physiology Renal Physiology, 312, F266-F275. https://doi.org/10.1152/ajprenal.00473.2016

[175] Shi, Y. and Vanhoutte, P.M. (2017) Macro- and Microvascular Endothelial Dysfunction in Diabetes. Journal of Diabetes, 9, 434-449.

https://doi.org/10.1111/1753-0407.12521

[176] Galvan, D.L., Green, N.H. and Danesh, F.R. (2017) The Hallmarks of Mitochondrial Dysfunction in Chronic Kidney Disease. Kidney International, 92, 1051-1057. https://doi.org/10.1016/j.kint.2017.05.034

[177] Kaur, R., Kaur, M. and Singh, J. (2018) Endothelial Dysfunction and Platelet Hyperactivity in Type 2 Diabetes Mellitus: Molecular Insights and Therapeutic Strategies. Cardiovascular Diabetology, 17, Article No. 121. https://doi.org/10.1186/s12933-018-0763-3

[178] Knapp, M., Tu, X. and Wu, R. (2019) Vascular Endothelial Dysfunction, a Major Mediator in Diabetic Cardiomyopathy. Acta Pharmacologica Sinica, 40, 1-8. https://doi.org/10.1038/s41401-018-0042-6

[179] Lightman, S. (1993) Does Aldose Reductase Have a Role in the Development of the Ocular Complications of Diabetes? Eye, 7, 238-241. https://doi.org/10.1038/eye.1993.56

[180] Jocelyn, J., Drinkwater, Davis, W.A. and Davis, T.M.E. (2019) A Systematic Review of Risk Factors for Cataract in Type 2 Diabetes. Diabetes/Metabolism Research and Reviews, 35, e3073. https://doi.org/10.1002/dmrr.3073

[181] Hashim, Z. and Zarina, S. (2012) Osmotic Stress Induced Oxidative Damage: Possible Mechanism of Cataract Formation in Diabetes. Journal of Diabetes and its Complications , 26, 275-279. https://doi.org/10.1016/j.jdiacomp.2012.04.005

[182] Maccari, R. and Ottanà, R. (2015) Targeting Aldose Reductase for the Treatment of Diabetes Complications and Inflammatory Diseases: New Insights and Future Directions. Journal of Medicinal Chemistry, 58, 2047-2067. https://doi.org/10.1021/jm500907a

[183] Huang, Q., Liu, Q. and Ouyang, D. (2019) Sorbinil, an Aldose Reductase Inhibitor, in Fighting Against Diabetic Complications. Medicinal Chemistry, 15, 3-7. https://doi.org/10.2174/1573406414666180524082445

[184] Quattrini, L. and la Motta, C. (2019) Aldose Reductase Inhibitors: 2013-Present. EX- 
pert Opinion on Therapeutic Patents, 29, 199-213. https://doi.org/10.1080/13543776.2019.1582646

[185] Vlassara, H. and Striker, G.E. (2013) Advanced Glycation Endproducts in Diabetes and Diabetic Complications. Endocrinology and Metabolism Clinics of North America, 42, 697-719. https://doi.org/10.1016/j.ecl.2013.07.005

[186] Brings, S., Fleming, T., Freichel, M., Muckenthaler, M.U., Herzig, S. and Nawroth, P.P. (2017) Dicarbonyls and Advanced Glycation End-Products in the Development of Diabetic Complications and Targets for Intervention. International Journal of Molecular Science, 18, 984. https://doi.org/10.3390/ijms18050984

[187] Simó-Servat, O., Planas, A., Ciudin, A., Simó, R. and Hernández, C. (2018) Assessment of Advanced Glycation End-Products as a Biomarker of Diabetic Outcomes. Endocrinología, Diabetes y Nutrición, 65, 540-545. https://doi.org/10.1016/j.endinu.2018.06.003

[188] Shen, H., Zhao, J., Liu, Y. and Sun, G. (2018) Interactions between and Shared Molecular Mechanisms of Diabetic Peripheral Neuropathy and Obstructive Sleep Apnea in Type 2 Diabetes Patients. Journal of Diabetes Research, 2018, Article ID: 3458615. https://doi.org/10.1155/2018/3458615

[189] Banarjee, R., Sharma, A., Bai, S., Deshmukh, A. and Kulkarni, M. (2018) Proteomic Study of Endothelial Dysfunction Induced by AGEs and Its Possible Role in Diabetic Cardiovascular Complications. Journal of Proteomics, 187, 69-79. https://doi.org/10.1016/j.jprot.2018.06.009

[190] Mori, H., Kuroda, A., Ishizu, M., Ohishi, M., Takashi, Y., Otsuka, Y., Taniguchi, S., Tamaki, M., Kurahashi, K., Yoshida, S., Endo, I., Aihara, K.I., Funaki, M., Akehi, Y. and Matsuhisa, M. (2019) Association of Accumulated Advanced Glycation End-Products with a High Prevalence of Sarcopenia and Dynapenia in Patients with Type 2 Diabetes. Journal of Diabetes Investigation, 10, 1332-1340. https://doi.org/10.1111/jdi.13014

[191] Qiu, S., Cai, X., Yin, H., Sun, Z., Zügel, M., Steinacker, J.M. and Schumann, U. (2018) Exercise Training and Endothelial Function in Patients with Type 2 Diabetes: A Meta-Analysis. Cardiovascular Diabetology, 17, Article No. 64. https://doi.org/10.1186/s12933-018-0711-2

[192] The Diabetes Control and Complications Trial Research Group (1993) The Effect of Intensive Treatment of Diabetes on the Development and Progression of Long-Term Complications in Insulin-Dependent Diabetes Mellitus. The New England Journal of Medicine, 329, 977-986. https://doi.org/10.1056/NEJM199309303291401

[193] Kabadi, U.M. (1999) DCCT: Medical and Economical Message, Five Years Later. Experimental and Clinical Endocrinology \& Diabetes, 107, S24-S29. https://doi.org/10.1055/s-0029-1212146

[194] Nathan, D.M. and DCCT/EDIC Research Group (2014) The Diabetes Control and Complications Trial/Epidemiology of Diabetes Interventions and Complications Study at 30 Years: Overview. Diabetes Care, 37, 9-16. https://doi.org/10.2337/dc13-2112

[195] Diabetes Control and Complications Trial [DCCT]/Epidemiology of Diabetes Interventions and Complications [EDIC] Study Research Group (2016) Intensive Diabetes Treatment and Cardiovascular Outcomes in Type 1 Diabetes: The DCCT/EDIC Study 30-Year Follow-Up. Diabetes Care, 39, 686-693. https://doi.org/10.2337/dc15-1990

[196] Diabetes Control and Complications Trial [DCCT]/Epidemiology of Diabetes Interventions and Complications [EDIC] Study Research Group (2016) Mortality in Type 1 Diabetes in the DCCT/EDIC Versus the General Population. Diabetes Care, 39, 1378-1383. https://doi.org/10.2337/dc15-2399

[197] Bebu, I., Braffett, B.H., Orchard, T.J., Lorenzi, G.M., Lachin, J.M. and DCCT/EDIC 
Research Group (2019) Mediation of the Effect of Glycemia on the Risk of CVD Outcomes in Type 1 Diabetes: The DCCT/EDIC Study. Diabetes Care, 42, 1284-1289. https://doi.org/10.2337/dc18-1613

[198] Testa, R., Bonfigli, A.R., Prattichizzo, F., la Sala, L., De Nigris, V. and Ceriello, A. (2017) The "Metabolic Memory" Theory and the Early Treatment of Hyperglycemia in Prevention of Diabetic Complications. Nutrients, 9, 437. https://doi.org/10.3390/nu9050437

[199] Miller, R.G. and Orchard, T.J. (2020) Understanding Metabolic Memory: A Tale of Two Studies. Diabetes, 69, 291-299. https://doi.org/10.2337/db19-0514

[200] Chalmers, J. and Cooper, M.E. (2008) UKPDS and the Legacy Effect. The New England Journal of Medicine, 359, 1618-1620. https://doi.org/10.1056/NEJMe0807625

[201] Laiteerapong, N., Ham, S.A., Gao, Y., Moffet, H.H., Liu, J.Y., Huang, E.S. and Karter, A.J. (2019) The Legacy Effect in Type 2 Diabetes: Impact of Early Glycemic Control on Future Complications (The Diabetes \& Aging Study). Diabetes Care, 42, 416-426. https://doi.org/10.2337/dc17-1144

[202] Qiu, S., Cai, X., Yin, H., Sun, Z., Zügel, M., Steinacker, J.M., Schumann, U. and Scheen, A.J. (2019) Effects of Glucose-Lowering Agents on Surrogate Endpoints and Hard Clinical Renal Outcomes in Patients with Type 2 Diabetes. Diabetes \& Metabolism, 45, 110-121. https://doi.org/10.1016/j.diabet.2018.10.003

[203] Chhipa, A.S., Borse, S.P., Baksi, R., Lalotra, S. and Nivsarkar, M. (2019) Targeting Receptors of Advanced Glycation End Products (RAGE): Preventing Diabetes Induced Cancer and Diabetic Complications. Pathology-Research and Practice, 215, Article ID: 152643. https://doi.org/10.1016/j.prp.2019.152643 